\title{
Fibroblast growth factor 8 regulates postnatal development of paraventricular nucleus neuroendocrine cells
}

\author{
Karla M. Rodriguez ${ }^{2 \dagger}$, Erica L. Stevenson ${ }^{1 \dagger}$, Courtney E. Stewart ${ }^{2}$, Megan L. Linscott ${ }^{1}$ and Wilson C. J. Chung ${ }^{1,2^{*}}$
}

\begin{abstract}
Background: Fibroblast growth factors (FGFs) are crucial signaling molecules that direct the development of the vertebrate brain. FGF8 gene signaling in particular, may be important for the development of the hypothalamuspituitary-adrenal (HPA)-axis. Indeed, newborn Fgf8 hypomorphic mice harbor a major reduction in the number of vasopressin (VP) neurons in the paraventricular nucleus (PVN), the central output component of the HPA-axis. Additionally, recent studies indicated that adult heterozygous ${ }^{+/ \text {/neo }}$ Fgf8 hypomorphic mice exhibit more anxiety-like behaviors than wildtype (WT) mice. These studies led us to investigate whether Fgf8 hypomorphy abrogated VP and/ or corticotropin-releasing hormone (CRH) neuronal development in the postnatal day (PN) 21 and adult mouse PVN. Furthermore, we studied whether Fgf8 hypomorphy disrupted HPA responsiveness in these mice.

Methods: Using immunohistochemistry, we examined the development of VP and CRH neurons located in the PVN of PN 21 and adult $\mathrm{Fgf8}^{+/ \text {neo }}$ mice. Moreover, we used a restraint stress (RS) paradigm and measured corticosterone levels with enzyme immunoassays in order to assess HPA axis activation.
\end{abstract}

Results: The number of VP neurons in the PVN did not differ between WT and Fgf8 ${ }^{+/ \text {neo }}$ mice on PN 21 and in adulthood. In contrast, CRH immunoreactivity was much higher in $\mathrm{Fgff}^{+/ \text {neo }}$ mice than in WT mice on PN 21, this difference was no longer shown in adult mice. RS caused a higher increase in corticosterone levels in adult $\mathrm{Fgfr}^{+/ \text {neo }}$ mice than in WT mice after 15 min, but no difference was seen after 45 min.

Conclusions: First, Fgf8 hypomorphy did not eliminate VP and CRH neurons in the mouse PVN, but rather disrupted the postnatal timing of neuropeptide expression onset in PVN neurons. Second, Fgf8 hypomorphy may, in part, be an explanation for affective disorders involving hyperactivity of the HPA axis, such as anxiety.

Keywords: Fibroblast growth factor 8, Corticotropin-releasing hormone, Vasopressin, HPA-axis, Stress

\section{Background}

Traditionally, fibroblast growth factor (FGF) signaling molecules are seen as crucial factors that direct the development of the vertebrate brain [1]. However, recent studies using genome-wide approaches on postmortem human brain tissue showed that patients suffering from major depressive disorder (MDD) contain significant

\footnotetext{
*Correspondence: wchung@kent.edu

${ }^{\dagger}$ Karla M. Rodriguez and Erica L. Stevenson contributed equally to this work

${ }^{1}$ Department of Biological Sciences, School of Biomedical Sciences, Kent State University, 53 Cunningham Hall, Kent, OH 44242, USA

Full list of author information is available at the end of the article
}

alteration in FGF gene expression, when compared to control patients. For instance, FGF1, FGF2, FGF receptor (FGFR) 2 and FGFR3 were significantly down-regulated in the frontal cortex of MDD patients, which strongly suggests that FGF signaling must be disrupted in mood disorders $[2,3]$. These data suggest that FGF function may not be limited to just embryonic or perinatal brain development, but extend well into the adult brain. Data from numerous clinical and basic studies have indicated that the hypothalamus-pituitary-adrenal (HPA) axis function exhibits major disruptions in affective disorders during adulthood. For instance, a recent study in middle-aged and aged MDD patients showed higher 
cortisol levels in the morning compared to aged control patients, which suggests hyperactivity of the HPA axis [4]. Together, these observations led us to infer that the FGF signaling system may play a role in the modulation of HPA function.

The activation of the HPA axis is controlled centrally by corticotropin-releasing hormone $(\mathrm{CRH})$, located in neurons found within the parvocellular subdivision of the paraventricular nucleus (PVN) of the hypothalamus. These $\mathrm{CRH}$ neurons project their axons to the median eminence [5-9], which upon a stressful stimulus will release the $\mathrm{CRH}$ peptide into the hypophyseal portal vein system to stimulate pituitary adrenocorticotropic hormone release into the general circulation, which then causes the release of the adrenal glucocorticoids in order to maintain body homeostasis [10]. Additional studies show that vasopressin (VP) has a supportive role in regulating the HPA axis [11]. Indeed, VP, co-expressed in $\mathrm{CRH}$ neurons in the PVN, potentiates $\mathrm{CRH}$ activity at the level of the pituitary corticotroph within the HPA axis, which in turn can lead to anxiety-like behaviors [9, 12, 13].

Recent studies using Fgf8 hypomorphic mice showed that the adult heterozygous $\left(^{+/ n e o}\right) F g f 8$ hypomorphic mice exhibited higher levels of anxiety than their wildtype (WT) counterparts [14, 15]. These behavioral studies were correlated with a reduction in the number of tryptophan hydroxylase (Tph; the rate-limiting enzyme for serotonin biosynthesis) expression in the dorsal raphe nucleus $\mathrm{Fgfl}^{+/ \text {neo }}$ mice when compared to WT mice [15]. Moreover, a follow-up study showed that the $F g f 8^{+/}$ neo dorsal raphe nucleus serotonergic neurons exhibited more c-FOS activation following restraint stress as compared to WT mice $[14,15]$. Together, these studies showed that the adult serotonergic function was compromised in $F g f 8^{+/ n e o}$ mice, thus leading to the possibility that FGF8 has the potential to affect the normal development of VP and CRH neurons individually.

Previous studies showed that FGF8 is a morphogen that regulates the normal development of the hypothalamic neuroendocrine cells [16-20]. For example, $F g f 8^{+/ \text {neo }}$ and $F g f 8^{\text {neo/neo }}$ newborn mice harbor approximately $20-40 \%$ less VP neurons in the PVN as compared to WT littermates [16]. Similarly, FGF8 signaling was important for the embryonic and perinatal development of other hypothalamic neuroendocrine cells, such as the oxytocinergic (OXT), gonadotropin-releasing hormone, and kisspeptinergic neurons [16, 18-20]. However, these studies did not investigate whether the deficiency in FGF8 expression also abrogated VP and/or CRH neuronal development in the young and adult mouse PVN, which represents the central output component of the HPA-axis. To answer this question, we first examined the effects of a deficiency in FGF8 signaling on the VP and CRH neuronal population in postnatal day PN 21 and adult PVN of Fgfs hypomorphic mice. Second, we assessed whether HPA-axis function in adult Fgf8 hypomorphic mice was compromised by examining corticosterone response following restraint stress.

\section{Methods \\ Transgenic animals}

Adult 129P2/OlaHsd*CD-1 (obtained from Mouse Regional Resource Centers) [17] male $F g f 8^{+/ \text {neo }}$ x female $F g f 8^{+/ n e o}$ mice were timed-bred in our animal facility on a 12L: 12D cycle with access to food and water ad libitum. All animal procedures were approved by the Institutional Animal Care and Use Committee at Kent State University. Postnatal day (PN) 21 and adult (6-8 weeks) studies were conducted in male WT or $F g f 8^{+/ \text {neo }}$ mice. $F g f 8^{\text {neo/neo }}$ mice die shortly after birth $[17,18]$. Fgf8 hypomorphic mice contain a neomycin-resistance element inserted into the non-coding region of the $F g f 8$ gene, which contains cryptic splice sites that cause an approximately $55 \%$ reduction in functional Fgf8 mRNA levels in $F g f 8^{\text {neo/neo }}$ mice [17]. Animals were genotyped using PCR for $F g f 8$ (F5'-AAGGGAACAGAGATTTGATG-3' and R5'-AGTCCACACCACCTCTCAAG-3'), and neomycin (N2/F2) (F5'-GATATTGCTGAAGAGCTTGGC-3' and R5'-GGTCTCCACAATGAGCTTC-3') [17].

\section{Brain tissue collection}

Brain tissue from PN 21 and adult mice were collected after euthanasia through decapitation, and were immersion-fixed in $4 \%$ paraformaldehyde/0.1 M phosphate buffer overnight and stored in $30 \%$ sucrose prior to coronal sectioning with a cryostat (Leica CM 1950, Buffalo Grove, IL). PN 21 and adult brain tissue was sectioned at $45 \mu \mathrm{m}$ in series of four.

\section{Immunohistochemistry}

Brain tissues from PN 21 (one of four series) and adult (one of four series) WT and $F g f 8^{+/ \text {neo }}$ mice were simultaneously processed. The staining conditions were standardized for each of the primary antibodies. These measures were taken in order to minimize the variability. Sections were incubated in $1 \%$ hydrogen peroxide in TBS solution for $15 \mathrm{~min}(\mathrm{~min})$ at room temperature, washed in TBS, $3 \times 5 \mathrm{~min}$ on a $2 \mathrm{D}$ rotator, and incubated in primary rabbit polyclonal anti-CRH $(1: 15,000$; PA1-37499, Thermo Fisher Scientific, Rockford, IL), rabbit polyclonal anti-VP $(1: 6000[19,20])$ or rabbit polyclonal anti-c-FOS (1:8000; Santa Cruz Biotechnologies, Santa Cruz, CA) diluted in TBS/0.3 \% Triton-X (Fisher Scientific, Pittsburgh, PA) and $2 \%$ normal goat serum for 2 days at $4{ }^{\circ} \mathrm{C}$. Sections were washed and incubated with 
a biotinylated-goat anti-rabbit (1:600) for $2 \mathrm{~h}$ at room temperature followed by $\mathrm{ABC}(1: 800)$ (Vector Laboratories, Burlingame, CA) in TBS for $2 \mathrm{~h}$ at room temperature, and reacted with $0.05 \%$ diaminobenzidine $+0.1 \%$ nickel ammonium sulfate (Sigma-Aldrich, St. Louis, $\mathrm{MO} / 0.01 \% \mathrm{H}_{2} \mathrm{O}_{2}$ in TBS for $20 \mathrm{~min}$. Following the color reaction, sections were dehydrated with increasing percentages of ethanol, and cleared with xylene prior to coverslipping with DPX (Merck, Billerica, MA.)

\section{Image analysis \\ VP and c-FOS cell number}

$V P$. Gray scale digital images of PN 21 (WT: $\mathrm{n}=7$, HET: $\mathrm{n}=4$ ) and adult (WT: $\mathrm{n}=4$, HET: $\mathrm{n}=4$ ) sections through the rostral-caudal extend of the PVN were captured using a $10 \times$ objective mounted on a Olympus microscope fitted with a color camera (SC30, Olympus, Corporation of the Americas, Center Valley, PA) connected to a PC computer. The distance between each immunostained section was $180 \mu \mathrm{m}$, which is significantly larger than the average PVN cell size of less than $70 \mu \mathrm{m}$ [21]. Total number of VP-IR neurons through the rostral-caudal bilateral extend of the PVN was quantified manually by an investigator without knowledge of the genotype of the animals. Only VP-IR neurons with a clearly visible nuclear compartment were included in our analysis. These criteria increased the stringency of our counts, and helped minimize double counts.

c-FOS. Gray scale digital images of adult (WT: $\mathrm{n}=4$, HET: $\mathrm{n}=4$ ) sections through the rostral-caudal extend of the PVN were captured using a $10 \times$ objective mounted on a Olympus microscope fitted with a color camera (SC30, Olympus, Corporation of the Americas, Center Valley, PA) connected to a PC computer. The distance between each immunostained section was $180 \mu \mathrm{m}$. Total number of c-FOS neurons through the rostral-caudal bilateral extend of the PVN was quantified manually by an investigator without knowledge of the genotype of the animals. Only c-FOS-IR neurons with a clearly visible nuclear compartment and nucleoli were included in our analysis. These criteria increased the stringency of our counts, and helped minimize double counts.

\section{CRH density}

Three rostral-caudal PN 21 (WT: $\mathrm{n}=4$, HET: $\mathrm{n}=4$ ) and adult (WT: $\mathrm{n}=4$, HET: $\mathrm{n}=4$ ) sections per individual animal, representative of the PVN, were matched using the fornix and optic chiasm as anatomical landmarks [22]. The distance between each section was $180 \mu \mathrm{m}$. These three grayscale digital images of the PVN per animal were captured using a $4 \times$ objective mounted on a Olympus microscope fitted with a color camera (SC30,
Olympus, Corporation of the Americas, Center Valley, PA) connected to a PC computer. The images were analyzed with Cell Sens (Olympus Corporation of the Americas, Center Valley, PA). We generated a standardized threshold mask which accurately covered the CRH immunoreactivity in WT mice. This threshold mask (PN $21=179$ grayscale value; adult $=127$ grayscale value) was then used to quantify bilaterally the CRH-IR density as immunoreactivity covered by pixels in a fixed rectangle $\left(\mathrm{PN} 21=567,490 \mu \mathrm{m}^{2}\right.$; adult $\left.=470,384 \mu \mathrm{m}^{2}\right)$. This method was choosing because we were not able to reliably discern the individual CRH-IR neurons. Furthermore, this method has been applied in past publications [23, 24]. Other methods of protein quantification, such as Western blotting, where also considered however not used for the following major reason: isolation and homogenization of the PVN would have meant the loss of precise anatomical localization of AVP and CRH neurons.

\section{Restraint stress}

In order to test HPA-axis responsiveness, adult male mice were randomly assigned to either no stress (NS) or restraint stress (RS) groups. Each group experienced the same testing procedures, except the NS mice were left in their cages, while the RS group were removed and restrained in ventilated restraint cones for 15 or $45 \mathrm{~min}$.

\section{Corticosterone enzyme-linked immunoassay}

Corticosterone levels in adult mice were measured immediately following $15 \mathrm{~min}$ of NS or RS condition (WT: $\mathrm{n}=5 \mathrm{NS}, \mathrm{n}=5$ RS; HET: $\mathrm{n}=5 \mathrm{NS}, \mathrm{n}=5 \mathrm{RS}$ ) and 45 min of NS or RS (WT: $\mathrm{n}=4 \mathrm{NS}, \mathrm{n}=4$ RS; HET: $\mathrm{n}=4 \mathrm{NS}, \mathrm{n}=4 \mathrm{RS}$ ). Their trunk blood collected into heparinized tubes, spun at $3000 \mathrm{rpm}$ to collect plasma, and stored at $-20{ }^{\circ} \mathrm{C}$ until the measurement of corticosterone levels by a commercial enzyme-linked immunoassay kit (ADI-900-097, Enzo Life Sciences) according to manufacturer's instructions. The intra- and inter-assay coefficients of variation were $6.6-8.4$ and $7.8-13.1 \%$, respectively, and the limit of detection was $26.99 \mathrm{pg} / \mathrm{mL}$.

\section{Statistical analysis}

Data were analyzed for significant differences with $t$ tests, one-way or two-way analysis of variance (ANOVA) with genotype and/or restraint stress as between subject variables. Student-Newman-Keuls tests were used for post hoc analysis. Differences were considered significant if $p<0.05$. Animals and treatments were randomized and coded by an independent investigator. All measurements were conducted by an observer without knowledge of the genotype of the animals. 


\section{Results}

\section{VP neurons in the PVN}

Two-tailed Student $t$ tests showed that the number of VP neurons did not differ between WT and $F g f 8^{+/ \text {neo }}$ mice in PN 21 (Fig. 1a: $\mathrm{t}=1.04, p=0.33$ ) and adults (Fig. 1b: $\mathrm{t}=-0.04, p=0.97)$.

\section{CRH density in the PVN}

In PN 21 mice, two-tailed Student $t$ tests showed that the $\mathrm{CRH}$ density in the PVN was significantly lower in WT than in $F g f 8^{+/ \text {neo }}(\mathrm{t}=-2.8, p<0.05)$ (Fig. 2i). In adult mice, two-tailed Student $t$ tests showed that CRH density was no longer significant $(\mathrm{t}=0.98, p<0.2)$ (Fig. 2j).

\section{Corticosteroid levels following restraint stress}

Fifteen minutes. Two-way analysis of variance showed that RS for 15 min caused a significant increase in circulating corticosterone levels in adult WT and $\mathrm{Fgfl}^{+/ \text {neo }}$ mice $(\mathrm{Df}=19, \mathrm{~F}=364.5, p<0.001)$. Moreover, there was a significant main genotype effect ( $\mathrm{Df}=19, \mathrm{~F}=5.5, p<0.05$ ), and interaction between restraint and genotype ( $\mathrm{Df}=19$, $\mathrm{F}=6.8, p<0.05)$. Student $t$ test analysis showed that the level of corticosterone was much higher in RS than NS WT and $F g f 8^{+/ \text {neo }}$ mice $(p<0.001)$. Furthermore, elevation of circulating corticosterone levels after RS was higher in $F g f 8^{+/ \text {neo }}$ mice than in WT mice $(p<0.003)$ (Fig. 3a).

Forty-five minutes. Two-way analysis of variance showed that RS stress for $45 \mathrm{~min}$ caused a significant
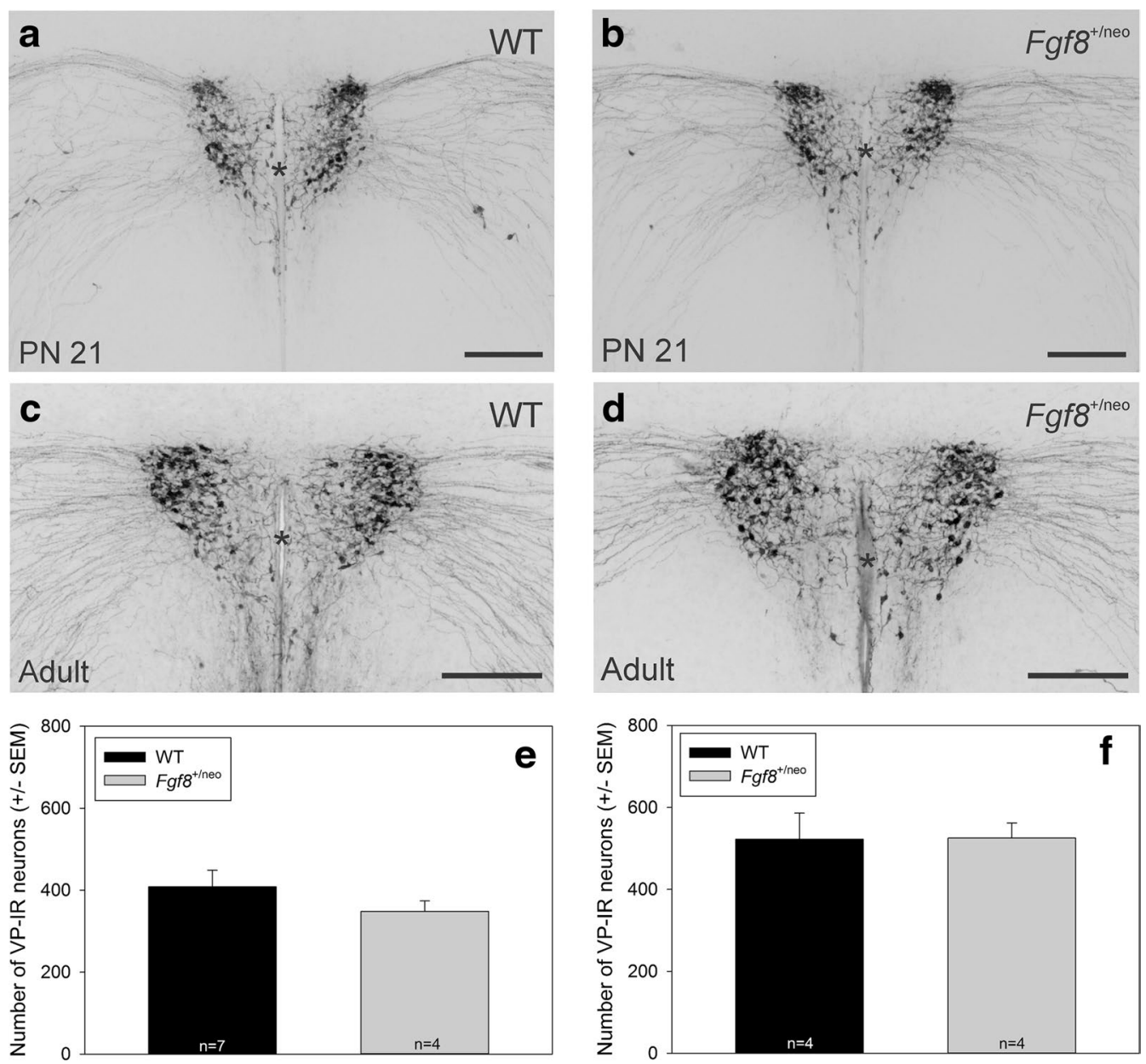

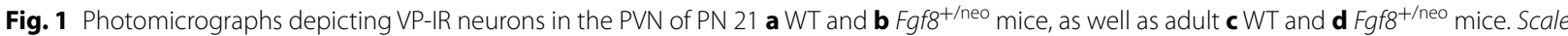
bar is $200 \mu \mathrm{m}$. Illustrations visually show no difference between genotypes. Asterisk indicates the third ventricle. Bar graphs depicting the mean number of VP-IR neurons in the PVN of e PN 21 and $\mathbf{f}$ adult mice. The number of VP-IR neurons did not differ between WT (408.3 \pm 40.4 sem) and $\mathrm{Fgf8}^{+/ \text {neo }}(348.5 \pm 25.3 \mathrm{sem})$ mice in PN 21 or in adult WT $(522.3 \pm 63.9 \mathrm{sem})$ and $\mathrm{Fgf8}^{+/ \text {neo }}(525.3 \pm 36.7 \mathrm{sem})$ mice 

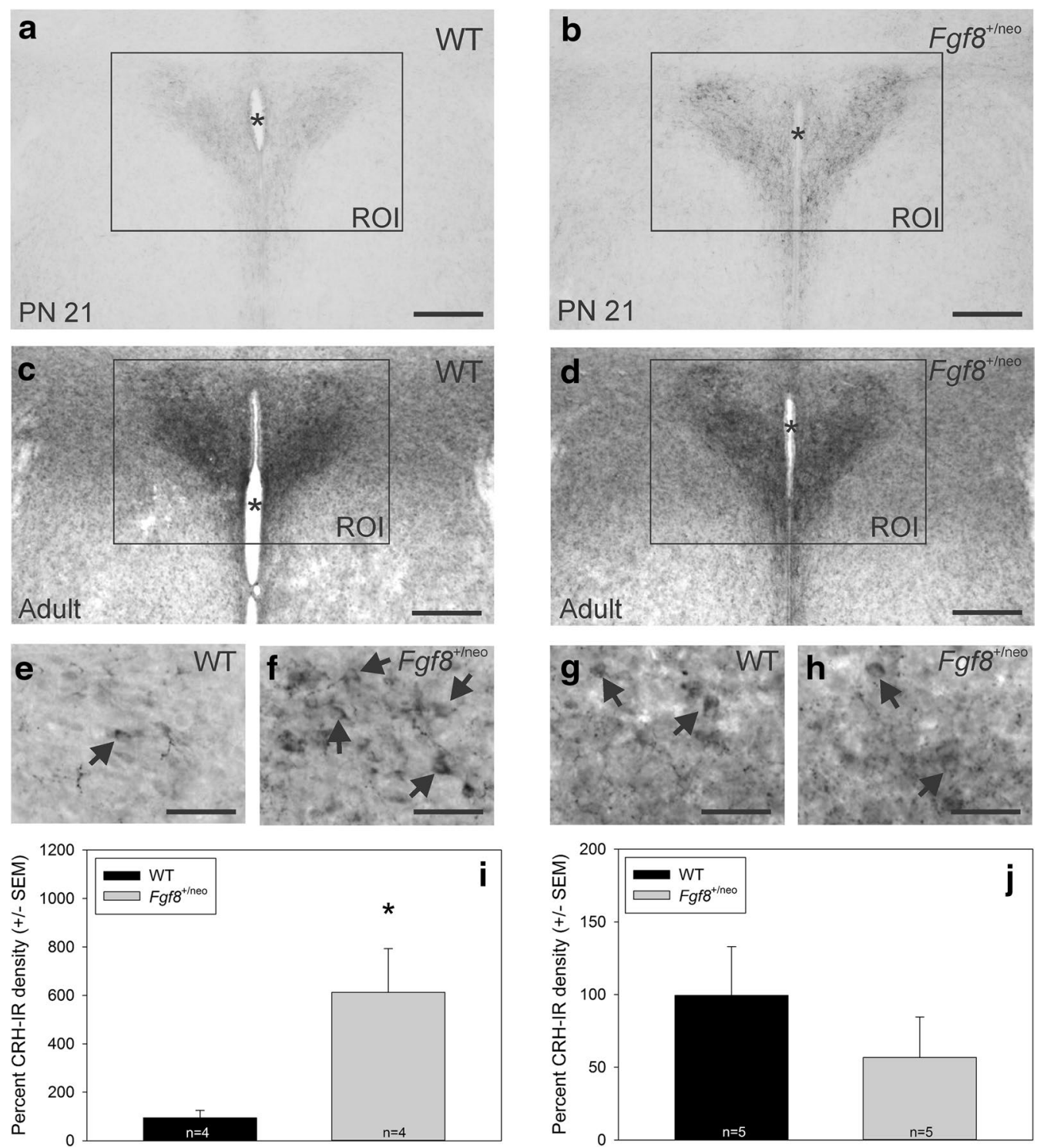

Fig. 2 Photomicrographs of CRH immunoreactivity in the PVN of PN21 a WT and $\mathbf{b}$ Fgf8 ${ }^{+/ \text {neo }}$ mice, as well as adult $\mathbf{c}$ WT and $\mathbf{d}$ Fgf8 ${ }^{+/ \text {neo }}$ mice. Scale bar is $200 \mu \mathrm{m}$. The ROI is the region of interest within which we calculated the CRH-IR density. Asterisk indicates the third ventricle. Higher magnification photomicrographs of CRH-IR cell bodies (arrows) in PN21 e WT, f Fgf8 ${ }^{+/ \text {neo }}$ and adult $\mathbf{g ~ W T , ~ h ~} \mathrm{Fgf8}^{+/ \text {neo }}$ mice. Scale bar is $50 \mu \mathrm{m}$. Bar graphs represent PVN CRH-IR density converted into relative percent change compared to the WT group of $\mathbf{i}$ PN 21 and $\mathbf{j}$ adult mice. i On PN 21, CRH-IR density was significantly lower in WT $\left(94.3 \pm 30.6 \%\right.$ sem) compared to $\mathrm{Fgf8}^{+/ \text {neo }}(613.0 \pm 179.8 \% \mathrm{sem})$ mice. The asterisk indicates $p<0.05$. $\mathbf{j}$ ln adulthood, CRH-IR density did not differ between WT $\left(99.4 \pm 33.5 \%\right.$ sem) and Fgf8 ${ }^{+/ \text {neo }}(56 \pm 27.8 \%$ sem) mice

increase in circulating corticosterone levels in adult $\mathrm{WT}$ and $\mathrm{Fg} f 8^{+/ \text {neo }}$ mice $(\mathrm{Df}=15, \mathrm{~F}=24.2, p<0.001$ ). However, there was no significant main genotypic effect $(\mathrm{Df}=19, \mathrm{~F}=0.6, p<0.4)$, or interaction between stress and genotype ( $\mathrm{Df}=15, \mathrm{~F}=0.5, p<0.5)$. Student $t$ test analysis showed that the level of corticosterone was much higher in RS than NS WT and $F g f 8^{+/ \text {neo }}$ mice $(p<0.001)$ (Fig. 3b).

\section{c-FOS neurons in the PVN}

Two-way analysis of variance showed that RS for $45 \mathrm{~min}$ caused a significant increase in the number of c-Fos-IR in the adult PVN in WT and $F g f 8^{+/ \text {neo }}$ mice (Df $=15$, $\mathrm{F}=119.4, p<0.001)$. However, there was no significant main genotypic effect ( $\mathrm{Df}=19, \mathrm{~F}=0.56, p=0.5$ ), or interaction between restraint stress and genotype $(\mathrm{Df}=19, \mathrm{~F}=0.29, p=0.6)$ (Fig. 4). 

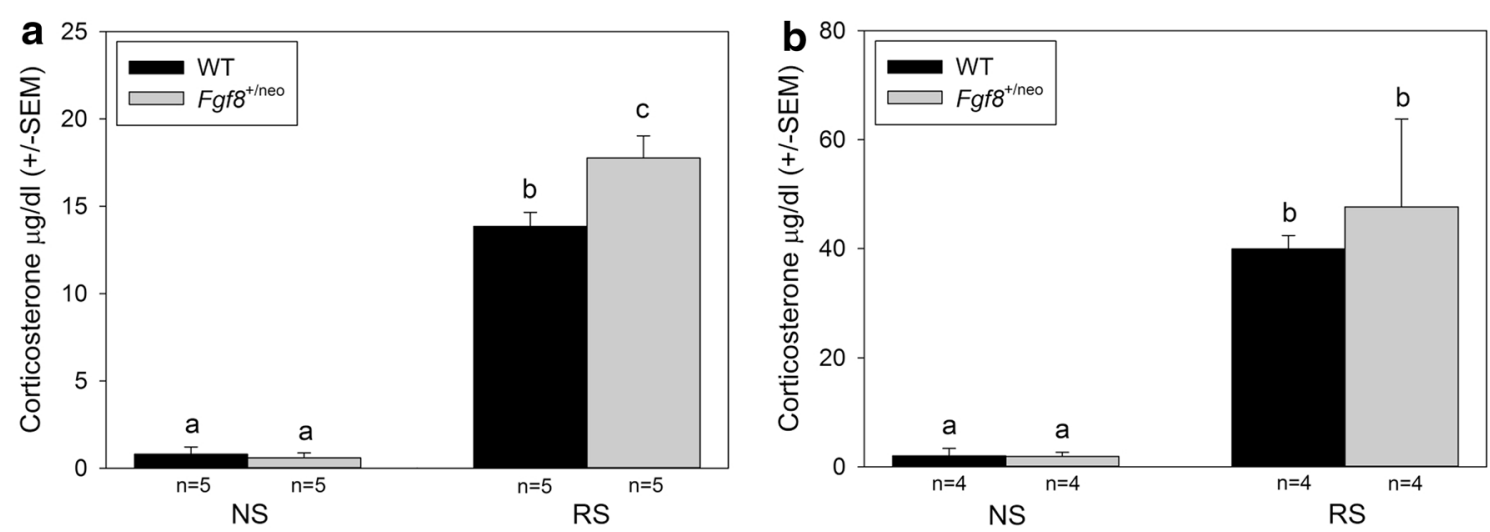

Fig. 3 Bar graphs depicting corticosterone levels in adult WT and Fgf8 ${ }^{+/ n e o}$ mice in response to RS for a 15 or $\mathbf{b} 45 \mathrm{~min}$. a RS for 15 min caused a significant rise in corticosteroid levels in WT $(13.8 \pm 0.8 \mu \mathrm{g} / \mathrm{dL})$ and Fgf8 ${ }^{+/ \text {neo }}$ mice $(17.8 \pm 1.3 \mathrm{sem} \mu \mathrm{g} / \mathrm{dL}) \mathrm{compared}$ to NS WT (0.8 $\pm 0.4 \mathrm{sem} \mu \mathrm{g} /$ $\mathrm{dL})$ and $\mathrm{Fgfl}^{+/ \mathrm{neo}}$ mice $(0.6 \pm 0.3 \mathrm{sem} \mu \mathrm{g} / \mathrm{dL})$. The rise in corticosteroid levels after 15 min of RS was significantly lower in WT than in Fgf8 ${ }^{+/ \text {neo }}$ mice. Differences in letters indicate $p<0.05$. b RS for 45 min caused a significant rise in corticosteroid levels in WT (40.0 $\pm 2.5 \mu \mathrm{g} / \mathrm{dL}$ ) and Fgf8 $/$ /neo $\mathrm{mice}$ $(47.7 \pm 16.1 \mathrm{sem} \mu \mathrm{g} / \mathrm{dL})$ compared to NS WT $(2.0 \pm 1.4 \mathrm{sem} \mu \mathrm{g} / \mathrm{dL})$ and Fgf8 ${ }^{+/ \text {neo }}$ mice $(1.9 \pm 0.7 \mathrm{sem} \mu \mathrm{g} / \mathrm{dL})$. The rise in corticosteroid levels after 45 min of RS did not differ between WT and Fgf8 ${ }^{+/ \text {neo }}$ mice. Asterisk indicates $p<0.05$ between animals treated with NS or RS conditions

\section{Discussion}

Fibroblast growth factor signaling directs the development of the vertebrate brain [1]. However, Fgf8 hypomorphy does not only affect neuronal development, but recent studies showed that abrogated FGF expression may have wide-spread neuropathological consequences during adulthood. Here, we showed that Fgfs hypomorphy in young and adult mice resulted in changes in postnatal CRH-IR density in the PVN. We found that whilst the CRH-IR density in the PN 21 PVN was much higher in $\mathrm{Fg} 8^{+/ \text {neo }}$ mice than in WT mice, this genotype-dependent difference was absent between $F g f 8^{+/ \text {neo }}$ mice and WT mice in adulthood. Moreover, in contrast to newborn mice, the VP-IR neuronal population in the PVN did not differ between WT and $F g f 8^{+/ \text {neo }}$ mice in PN 21 and adulthood [16]. Interestingly, notwithstanding that the VP and CRH immunoreactivity were fully normalized between WT and $F g f 8^{+/ \text {neo }}$ adult mice, we found that adult $F g f 8^{+/ \text {neo }}$ mice mounted a slightly faster, but significantly, corticosterone rise than WT mice in response to RS. From these observations and previous data, we infer that $F g f 8$ expression is required for the continued postnatal development/maturation of the VP and CRH neurons in the PVN, and that disruption of this process causes the adult HPA-axis in $\mathrm{Fgfl}^{+/}$ neo mice to be slightly hyper-responsive when challenged with RS.

Earlier studies found that the number of VP-IR neurons in the PVN was reduced in $F g f 8^{+/ \text {neo }}$ and $F g f 8^{\text {neo/neo }}$ mice compared to WT mice [16], which may compromise the activation or function of the HPA axis. It has been well-established that Fgf8 hypomorphy causes abnormal apoptotic cell death during embryonic cortical and olfactory placode development $[25,26]$, which resulted in permanent morphological and neurochemical changes, such as cortical thinning and the elimination of gonadotropin-releasing hormone neurons [25-27]. Based on these previous data, we hypothesized that the loss of VP-IR neurons found in the newborn Fgf8 hypomorphic mice [16] was due to the elimination of embryonic PVN neurons that were destined to express VP. This hypothesis led us to predict that the loss of VP-IR neurons in PVN was permanent, and therefore, would be detectable in PN 21 and adult mice. To our surprise, the number of VP-IR neurons did not differ between WT and $F g f 8^{+/ \text {neo }}$ mice in PN 21 or adulthood. These results led us to conclude that Fgf8 hypomorphy-dependent premature apoptosis in the PVN was not the cause for the reduced number of the VP-IR neurons in the newborn Fgf8 hypomorphic PVN. The most logical explanation is that the newborn and postnatal $\mathrm{Fgf}^{+/ \text {neo }}$ hypomorphic PVN actually are comprised with a normal complement of neurons that are able to express VP, and that this expression is disturbed by the deficiency in FGF8 signaling. Previous studies showed that oxytocin expressing PVN neurons are similarly reduced in $F g f 8$ hypomorphic newborn mice, which has been posited to be due to a disruption of the posttranslational processing of the oxytocin prohormone to mature oxytocin [28]. Although, this possibility may have caused the reduction in VP-IR neurons in the newborn $\mathrm{PVN}$, it is far more likely that $F g f 8$ hypomorphy interfered VP gene transcription. Indeed, in situ hybridization studies showed a dramatic reduction of VP mRNA expression in the newborn Fgf8 hypomorphic PVN [16]. 


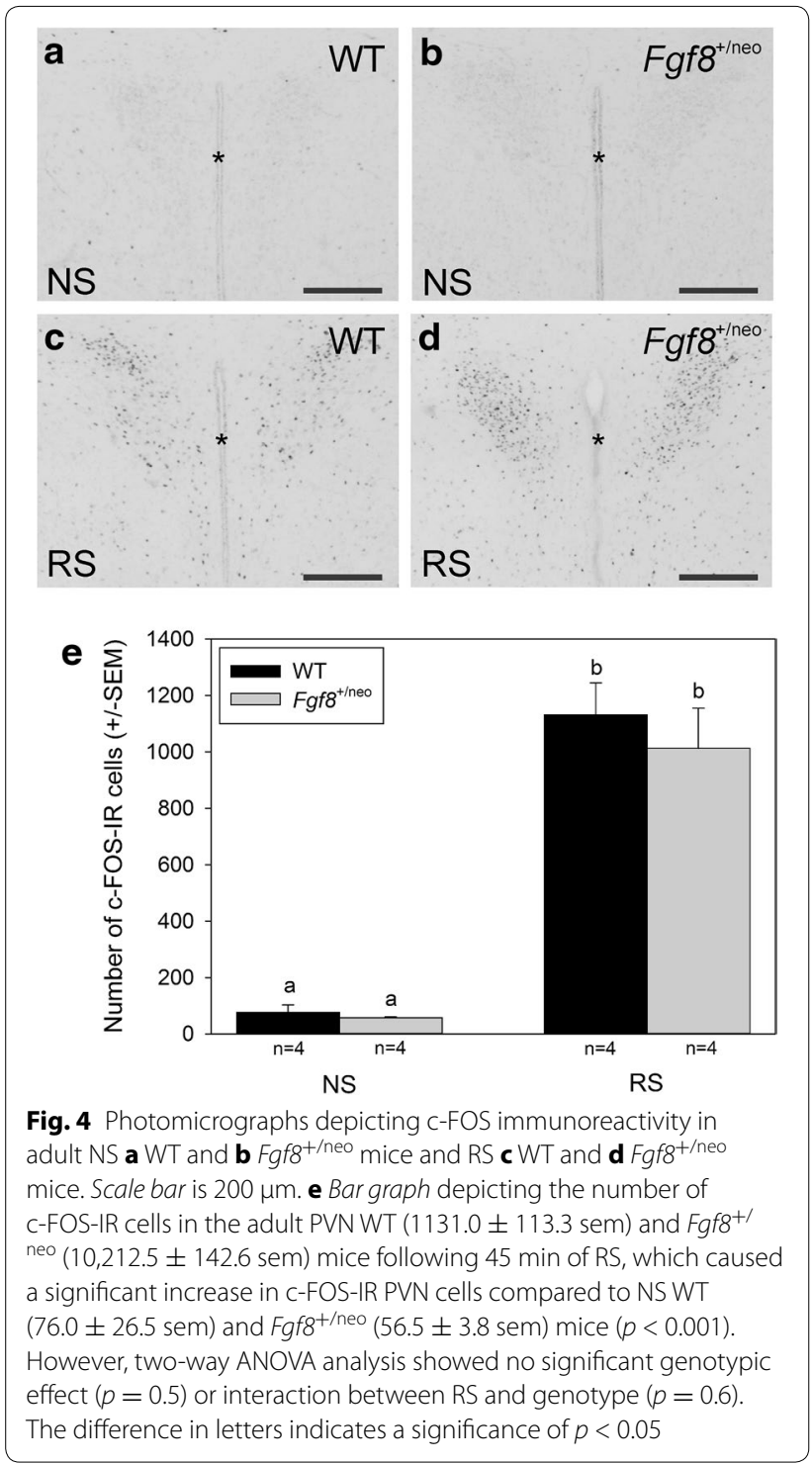

In contrast to the VP-IR neurons in the PVN, CRH-IR neuronal density in the PVN was much higher in $\mathrm{Fg} \mathrm{8}^{+/ \text {neo }}$ mice as compared to WT mice in PN 21, which was found to be fully normalized between WT and $F g f 8^{+/ \text {neo }}$ mice in adulthood. These data then led us to a reinterpretation of the role FGF8 has in the mammalian brain. FGF8 signaling may remain relevant during postnatal PVN development and/or function. Specifically, we hypothesize that FGF8 signaling may regulate the timing of neuropeptide expression onset in postnatal PVN neurons as supported by the $F g f 8$ hypomorphy-dependent delay in VP expression and advancement of $\mathrm{CRH}$ expression in postnatal PVN neurons. Currently, more studies are required to fully investigate and explore the validity of this hypothesis.

Although, VP and CRH expression was normalized between WT and $F g f 8^{+/ \text {neo }}$ adult mice, the rise in the corticosterone levels after 15 min of RS in adult $F g f 8^{+/ \text {neo }}$ mice was faster than in WT mice, which was no longer detectable after $45 \mathrm{~min}$ of RS. These basic experimental studies are in line with previous behavioral studies suggesting that the HPA axis in $F g f 8^{+/ \text {neo }}$ mice may be hyperactive $[14,15]$. Indeed, $F g f 8^{+/ \text {neo }}$ hypomorphic mice exhibited higher levels of anxiety-like behavior, which coincided with a reduction in the number of Tphexpressing neurons in the dorsal raphe nucleus [15]. Interestingly, in a follow-up study $F g f 8^{+/ \text {neo }}$ dorsal raphe nucleus serotonergic neurons exhibited more c-FOS activation following $R S$ as compared to WT mice [14, 15]. These studies showed that the adult serotonergic function was compromised in $\mathrm{Fg} \mathrm{f}^{+/ \text {neo }}$ mice, which together with the abnormal postnatal development of the VP and $\mathrm{CRH}$ neurons in the PVN may be the underlying cause of Fgf8 hypomorphy-dependent HPA axis hyperactivity, and increased anxiety-like behaviors.

Fibroblast growth factor-dependent disruption of HPA function may contribute to the onset of other affective disorders, such as MDD. For instance, genome-wide studies in postmortem human brain tissue from patients with MDD showed that they harbored significant abnormalities in FGF expression in the frontal cortex, when compared to control patients [2, 3]. Specifically, FGF1, FGF2, FGF receptor (FGFR) 2 and FGFR3 were down-regulated in the frontal cortex of MDD patients, which strongly suggests that FGF signaling must be disrupted in mood disorders [2, 3]. Based on our studies showing an artificial partial inactivation of FGF8 signaling in the young and adult mouse, we postulate that FGF8 signaling may similarly be involved and individuals with inactivating mutations in $F g f 8$ may be predisposed to affective disorders.

\section{Conclusion}

Here, our studies led us to conclude that FGF8 signaling remains very important for the ongoing postnatal development of the PVN in young and adult mice. First, partial inactivation of FGF8 signaling did not lead to the elimination of VP and CRH neurons that reside in the mouse PVN, but rather caused a disruption in the postnatal timing of neuropeptide expression onset in PVN neurons. Second, Fgf8 hypomorphy may, in part, be an explanation for affective disorders involving hyperactivity of the HPA axis, such as anxiety and MDD.

\section{Authors' contributions}

Authors contributed equally to writing of paper. ELS, KMR and WCJC ran IHCS and analysis. MLL and CES contributed by doing animal work, tissue collecting and tissue processing. All authors read and approved the final manuscript.

\section{Author details}

${ }^{1}$ Department of Biological Sciences, School of Biomedical Sciences, Kent State University, 53 Cunningham Hall, Kent, OH 44242, USA. ${ }^{2}$ School of Biomedical Sciences, Kent State University, Kent, OH 44242, USA. 


\section{Acknowledgements}

This work was funded by NICHD (4R00HD058044) to WCJC.

\section{Competing interests}

The authors declare that they have no competing interests.

Received: 22 June 2015 Accepted: 26 October 2015

Published online: 04 November 2015

\section{References}

1. Crossley PH, Martin GR. The mouse Fgf8 gene encodes a family of polypeptides and is expressed in regions that direct outgrowth and patterning in the developing embryo. Development (Cambridge, England). 1995;121(2):439-51.

2. Evans SJ, Choudary PV, Neal CR, Li JZ, Vawter MP, Tomita H, et al. Dysregulation of the fibroblast growth factor system in major depression. Proc Natl Acad Sci USA. 2004;101(43):15506-11. doi:10.1073/pnas.0406788101.

3. Turner CA, Watson SJ, Akil H. The fibroblast growth factor family: neuromodulation of affective behavior. Neuron. 2012;76(1):160-74. doi:10.1016/j.neuron.2012.08.037.

4. Bhagwagar Z, Hafizi S, Cowen PJ. Increased salivary cortisol after waking in depression. Psychopharmacology. 2005;182(1):54-7. doi:10.1007/ s00213-005-0062-z.

5. Koegler-Muly SM, Owens MJ, Ervin GN, Kilts CD, Nemeroff CB. Potential corticotropin-releasing factor pathways in the rat brain as determined by bilateral electrolytic lesions of the central amygdaloid nucleus and the paraventricular nucleus of the hypothalamus. J Neuroendocrinol. 1993:5(1):95-8.

6. Lind RW, Swanson LW, Sawchenko PE. Anatomical evidence that neural circuits related to the subfornical organ contain angiotensin II. Brain Res Bull. 1985;15(1):79-82.

7. Sawchenko PE, Swanson LW, Vale WW. Corticotropin-releasing factor: co-expression within distinct subsets of oxytocin-, vasopressin-, and neurotensin-immunoreactive neurons in the hypothalamus of the male rat. I neurosci off J Soc Neurosci. 1984:4(4):1118-29.

8. Vale WW, Rivier C, Perrin M, Smith M, Rivier J. Pharmacology of gonadotropin releasing hormone: a model regulatory peptide. Adv Biochem Psychopharmacol. 1981;28:609-25.

9. Whitnall MH, Key S, Ben-Barak Y, Ozato K, Gainer H. Neurophysin in the hypothalamo-neurohypophysial system. II. Immunocytochemical studies of the ontogeny of oxytocinergic and vasopressinergic neurons. I neurosci off J Soc Neurosci. 1985;5(1):98-109.

10. Sayers G. The adrenal cortex and homoestasis. Physiol Rev. 1950;30(3):241-320

11. Herman JP, Wiegand SJ, Watson SJ. Regulation of basal corticotropinreleasing hormone and arginine vasopressin messenger ribonucleic acid expression in the paraventricular nucleus: effects of selective hypothalamic deafferentations. Endocrinology. 1990;127(5):2408-17. doi:10.1210/ endo-127-5-2408

12. Raadsheer FC, Tilders FJ, Swaab DF. Similar age related increase of vasopressin colocalization in paraventricular corticotropin-releasing hormone neurons in controls and Alzheimer patients. J Neuroendocrinol. 1994;6(2):131-3

13. Rivier $C$, Vale W. Interaction of corticotropin-releasing factor and arginine vasopressin on adrenocorticotropin secretion in vivo. Endocrinology. 1983;113(3):939-42. doi:10.1210/endo-113-3-939.

14. Brooks LR, Enix CL, Rich SC, Magno JA, Lowry CA, Tsai PS. Fibroblast growth factor deficiencies impact anxiety-like behavior and the serotonergic system. Behav Brain Res. 2014;264:74-81. doi:10.1016/j. bbr.2014.01.053.
15. Brooks LR, Pals HL, Enix CL, Woolaver RA, Paul ED, Lowry CA, et al. Fibroblast growth factor 8 deficiency compromises the functional response of the serotonergic system to stress. PLoS One. 2014;9(7):e101420. doi:10.1371/journal.pone.0101420.

16. McCabe MJ, Gaston-Massuet C, Tziaferi V, Gregory LC, Alatzoglou KS, Signore M, et al. Novel FGF8 mutations associated with recessive holoprosencephaly, craniofacial defects, and hypothalamo-pituitary dysfunction. J clin endocrinol metab. 2011;96(10):E1709-18. do:10.1210/ jc.2011-0454

17. Meyers EN, Lewandoski M, Martin GR. An Fgf8 mutant allelic series generated by Cre- and Flp-mediated recombination. Nat Genet. 1998;18(2):136-41. doi:10.1038/ng0298-136.

18. Chung WC, Moyle SS, Tsai PS. Fibroblast growth factor 8 signaling through fibroblast growth factor receptor 1 is required for the emergence of gonadotropin-releasing hormone neurons. Endocrinology. 2008;149(10):4997-5003. doi:10.1210/en.2007-1634.

19. de Vries GJ, Buijs RM, Swaab DF. Ontogeny of the vasopressinergic neurons of the suprachiasmatic nucleus and their extrahypothalamic projections in the rat brain-presence of a sex difference in the lateral septum. Brain Res. 1981;218(1-2):67-78.

20. Erkut ZA, Gabreels BA, Eikelenboom J, van Leeuwen FW, Swaab DF. Glucocorticoid treatment is associated with decreased expression of processed AVP but not of proAVP, neurophysin or oxytocin in the human hypothalamus: are PC1 and PC2 involved? Neuro endocrinol lett. 2002;23(1):33-44.

21. van den Pol AN. The magnocellular and parvocellular paraventricular nucleus of rat: intrinsic organization. J Comp Neurol. 1982;206(4):317-45. doi:10.1002/cne.902060402.

22. Franklin KBJ, Paxinos $\mathrm{G}$. The mouse brain in stereotaxic coordinates. 3rd ed. Elsevier; 2008.

23. Austin MC, Janosky JE, Murphy HA. Increased corticotropin-releasing hormone immunoreactivity in monoamine-containing pontine nuclei of depressed suicide men. Mol Psychiatr. 2003;8(3):324-32. doi:10.1038/ sj.mp.4001250.

24. Swaab DF, Chung WC, Kruijver FP, Hofman MA, Hestiantoro A. Sex differences in the hypothalamus in the different stages of human life. Neurobiol Aging. 2003;24(Suppl 1):S1-16 (Discussion S7-9)

25. Storm EE, Garel S, Borello U, Hebert JM, Martinez S, McConnell SK, et al. Dose-dependent functions of Fgf8 in regulating telencephalic patterning centers. Development (Cambridge, England). 2006;133(9):1831-44. doi:10.1242/dev.02324.

26. Tsai PS, Brooks LR, Rochester JR, Kavanaugh SI, Chung WC. Fibroblast growth factor signaling in the developing neuroendocrine hypothalamus. Front Neuroendocrinol. 2011;32(1):95-107. doi:10.1016/j. yfrne.2010.11.002.

27. Kawauchi S, Shou J, Santos R, Hebert JM, McConnell SK, Mason I, et al. Fgf8 expression defines a morphogenetic center required for olfactory neurogenesis and nasal cavity development in the mouse. Development (Cambridge, England). 2005;132(23):5211-23. doi:10.1242/dev.02143.

28. Brooks LR, Chung WC, Tsai PS. Abnormal hypothalamic oxytocin system in fibroblast growth factor 8-deficient mice. Endocrine. 2010;38(2):17480. doi:10.1007/s12020-010-9366-9.

\section{Submit your next manuscript to BioMed Central and take full advantage of:}

- Convenient online submission

- Thorough peer review

- No space constraints or color figure charges

- Immediate publication on acceptance

- Inclusion in PubMed, CAS, Scopus and Google Scholar

- Research which is freely available for redistribution

Submit your manuscript at www.biomedcentral.com/submit 